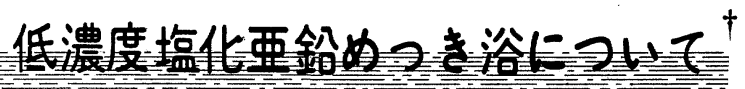

\section{最近, 公害問題および省資源の面から低濃}

度化された塩化亜鉛めっき浴が開発された。

従来の塩化亜鉛めっき液にくらへてて, 光沢,

レベリング，均一電着性，硬さなどにすぐれ

た特徵を持つこの液について紹介する。

\section{1.はじめに}

塩化亜鉛めっき浴が工業化されてから約 10 年核どになるが，他のシアン浴やジンケート 浴に比べて生産性が大であること，水素ぜい 性が起きにくいなど多くの長所があることか ら, 広人, 自動車, 航空機, 弱電, 建築部 品, 線材, 鋼材などのめっきに用いられてき た。しかし, 従来の塩化亜鉛浴では, 均一電 着性や硬さの面で，シアン浴などと比べると 劣る面もあった。

しかしながら，最近，公害問題および省資 源の面から低濃度化されてきた塩化亜鉛めっ さ浴の開発により, 従来の塩化浴の欠点で㐫 った均一霞着性や碩さの面でも非常に優れた めっき浴が完成されたのでここに紹介する。

\section{2. 低濃度塩化亜鉛浴の特徵}

低濃度塩化刺鉛浴の組成および使用条件を
表 1 亿示す。

\section{2-1 陰極電流効率}

図 1 は各種浴の陰極電流効摔を, 図 2 は浴 組成の変化と陰極電流效率の関係を示す。効 率は硫酸銅めっきとの比較から求めた。塩化 亜鉛浴の陰極電流効率恃，電流密度が高くな っても, シアン浴やジンッート浴のよう急 激に低下しない。

塩化アンモニウムの濃度が高くなるにつれ

表 1 標準浴組成抒よび使用条件

\begin{tabular}{l|c|c}
\hline & 使用範囲 & 標 準 \\
\hline 塩化塜鉛 & $20 \sim 80 \mathrm{~g} / l$ & $40 \mathrm{~g} / l$ \\
塩化アンモニウム & $150 \sim 250 \mathrm{~g} / l$ & $200 \mathrm{~g} / l$ \\
$\mathrm{~S} \mathrm{~T}-\mathrm{L}$ & $20 \sim 60 \mathrm{ml} / l$ & $30 \mathrm{ml} / l$ \\
$\mathrm{~A}-\mathrm{L}$ & $0.5 \sim 2.5 \mathrm{ml} / l$ & $1.5 \mathrm{ml} / l$ \\
\hline $\mathrm{pH}$ & $5.0 \sim 6.5$ & 5.8 \\
温 度 & $15 \sim 40^{\circ} \mathrm{C}$ & $27^{\circ} \mathrm{C}$ \\
陰極電流密度 & $0.5 \sim 7 \mathrm{~A} / \mathrm{dm}^{2}$ & $2 \mathrm{~A} / \mathrm{dm}^{2}$ \\
陽極電流密度 & $1 \sim 10 \mathrm{~A} / \mathrm{dm}^{2}$ & $2 \mathrm{~A} / \mathrm{dm}^{2}$ \\
\hline 浴電压 & $3 \sim 10 \mathrm{~V}$ \\
\hline
\end{tabular}

*Motonobu Kubo C. Uyemura \& Co., Ltd 1-5-1, Deguchi, Hirakata-shi, Osaka 573 


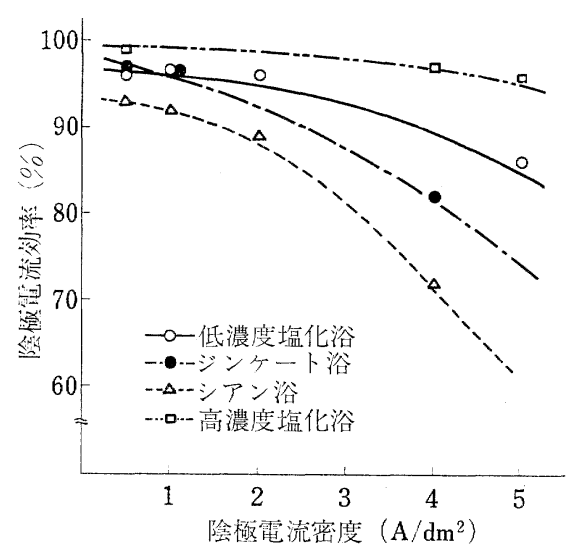

図 1 各種浴の陰極電流効率

て，㓌極電流效率は除々に低くなるが，塩化 亜鉛の濃度が $40 \mathrm{~g} / l$ 以上では， 汪とんど影響 はない。

このように，塩化覀鉛浴は㓌極電流效率が 高いため，めっき速度が大であり生産性が向 上することになる。

\section{2-2 均一電着性}

ハーリング・ブラム法により距離比 $3 ： 1$ で測定した。計算は距離比に関係なく，同じ 重量の析出物が得られたとさを $100 \%$ とする フィールドの式を用いた。図 3 は各種浴の均 一電着性, 図 4 は塩化亜鉛の濃度変化による

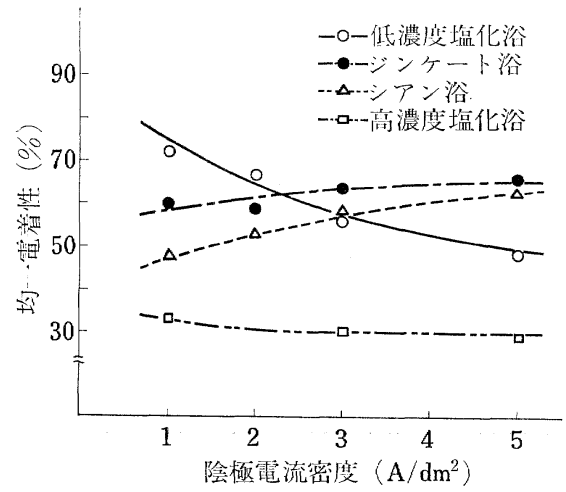

図 3 各種浴の均一電着性

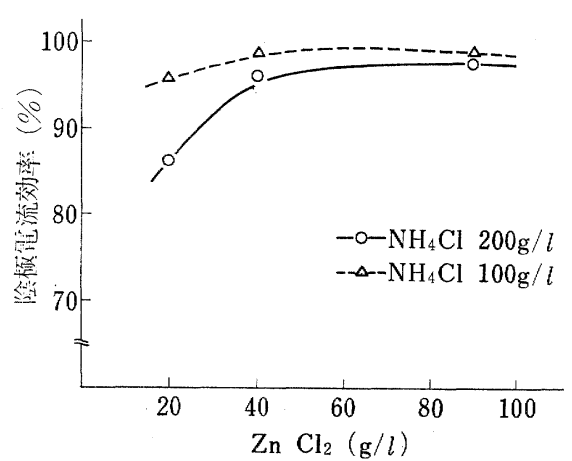

図 2 浴組成の変化之陰極電流効率(陰極電 流密度一 $1 \mathrm{~A} / \mathrm{dm}^{2}$ 一定)

均一電着性である。

從来の高濃度塩化覀鉛浴は, シアン浴, ジ ソケート浴に比べると均一電着性はやはり劣 っている。しかし，低濃度塩化亜鉛浴は，シ アン浴, ジンケート浴の均一電着性とほとん ど同等で,むしろ， $2.5 \mathrm{~A} / \mathrm{dm}^{2}$ 以下ではジン ケート浴, シアン浴に比べてかなり良くなる 傾向にある。

塩化覀鉛の濃度が $40 \mathrm{~g} / l$ 以下，すなわち低 濃度塩化亜鉛浴では均一電着性は非常によく なっている。

\section{2-3 水素ぜい性}

スプリングワッシャーの捻回試験からら水素

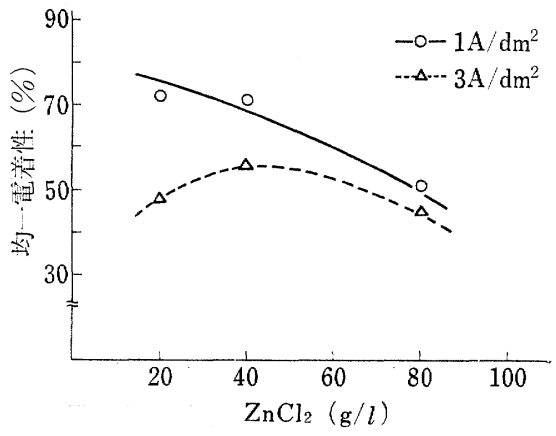

図 4 塩化亜鉛の濃度変化による均一電着性 $\left(\mathrm{NH}_{4} \mathrm{Cl} 200 \mathrm{~g} / l\right.$ 一定 $)$ 
ぜい性の程度を類推した。低濃度塩化亜鉛 浴, ジンケート浴, シアン浴とも $10 \mathrm{~A} / \mathrm{kg}$ で スプリングワッシャーをめっきし，めっき厚 $8 \pm 1 \mu \mathrm{m}$ のものを用いて，これらのワッシ ヤ一を $80^{\circ} \sim 250^{\circ}$ の間で捻回し折れた時点の 角度を測定した。

その結果，角度の分布を調べると素材自身 で202で折れの分布のピークが現われ，低濃 度塩化浴で $193^{\circ}$, ジンケート浴 $175^{\circ}$, シアン 浴 $186^{\circ}$ となった。このように塩化坐鉛浴から のめっきは, シアン浴, ジンケート浴からの めっきに比べて水素ぜい性が起きにくいこと がわかる。

このことにより, 自動車部品, 航空機部品 のめっき塩化亜鉛浴が広く用いられている わけである。

\section{2-4 硬さ}

ビッカース硬さ計で，試料はめっき厚 $20 \mu$ $\mathrm{m}$ にし, 荷重 $25 \mathrm{~g}$ で測定した。表 2 は各種浴 の標準組成での硬さ，おび゙低濃度塩化浴で の光沢剤の添加量変化に捄ける硬さを示し た。

従来の高濃度塩化浴の場合, ジンケート浴 と同樣に，やはりシアン浴に比べると硬かっ た。乙か乙, 低濃度塩化浴の場合, ビッカー ス硬さで50〜70と，洁とんどシアン浴と同等 の硬さである。

従来, 硬さの面でどうしてもシアン浴を用 いなケればならなかった場合でも，この低濃 度塩化亜鉛浴を用いることによりノーシアン

表 2 各種浴の硬さ

\begin{tabular}{|c|c|c|c|c|c|c|c|}
\hline \multicolumn{6}{|c|}{ 低濃度塩化 浴 } & \multirow{3}{*}{$\begin{array}{l}\text { ジ } \\
\text { 年 } \\
\text { ケ } \\
\vdots \\
5 \\
\text { 浴 }\end{array}$} & \multirow{3}{*}{$\begin{array}{c}\text { シ } \\
\text { P } \\
\text { ン } \\
\text { 浴 }\end{array}$} \\
\hline SFL & $\begin{array}{c}30 \\
\mathrm{ml} / \mathrm{l}\end{array}$ & 30 & 30 & 1.5 & 60 & & \\
\hline$A-L$ & $\begin{array}{l}1.5 \\
\mathrm{ml} / l\end{array}$ & 0.75 & 3 & 1.5 & 1.5 & & \\
\hline $\begin{array}{l}\text { 硬 } \\
\text { さ }\end{array}$ & $\begin{array}{c}58 \\
(\mathrm{Hv})\end{array}$ & 56 & 72 & 76 & 70 & $\begin{array}{l}90 \sim \\
130\end{array}$ & $\begin{array}{c}30 \sim \\
70\end{array}$ \\
\hline
\end{tabular}

化することが可能となったわけである。ま た，光沢剤の添加量が多くなると少し硬くな り，陰極電流密度が高くなると若干硬くなる 傾向にある。

\section{2-5 エリクセン試験}

めっき皮膜の物性を比較するすのとしてエ リクセン試験があるが，これはめっき皮膜の 脆さを比較するために，めっき厚 $8 \mu \mathrm{m}$ の鉄 板をエリクセン試験器により $5 \mathrm{~mm}$ 押し出 し，金属頭微鏡で割引を拡大乙観察した。低 濃度塩化两鉛浴は，シアン浴と同等で割れは 不規則であり, ジンケート浴のようにめっさ が剥がれてしまうことがない。光沢剂添加量 との関係は，多くなると若干脆くなる傾向が ある。

\section{2-6 起泡力}

従来の塩化业鉛浴の場合, 光沢剤による浴 の泡立らが多くめっき括よび廃水処理で問題 となることがあったが，低濃度塩化亜鉛浴の 光沢剂の場合活とんど泡立ちがない。起泡力 の試験として $100 \mathrm{ml}$ の有栓メスシリンダー に, めっき液を $50 \mathrm{ml}$ 入れ，20秒上く振り泡 立ちの高さの経時変化を調べた。従来の浴と 比較して，全く泡立ちがないことを示してい る(図 5 参照)。

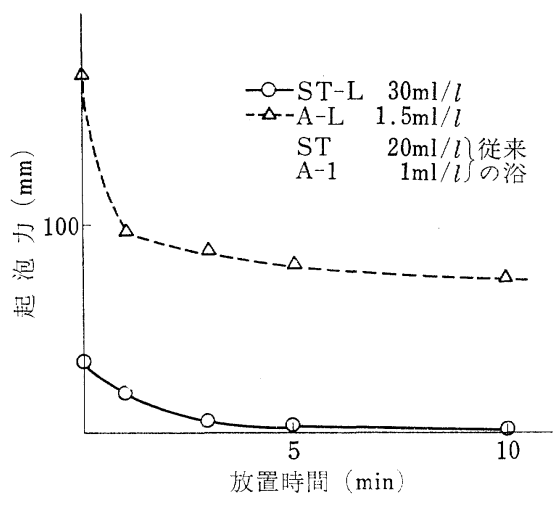

図 5 めっき浴の起泡力試験 


\section{3. 低濃度塩化垔鉊浴の 管理上の留意点}

\section{3-1 めっき浴の管理}

めっき浴を管理する上で重要な塩化亜鉛の 濃度, 塩化アンモニウムの濃度, 光沢剤の添 加量, 浴の温度, $\mathrm{pH}$ がめっきの諸性質であ る光沢, つきまわり, 電流効率, 高電流のコ ゲ, バレルの斑点, 浴のにごり, 硬さに対し てどのような傾向にあるかまとめてみると以 下のようになる。

光沢は, 光沢剂の添加量に比例して光沢は 增すが，浴温が $35^{\circ} \mathrm{C}$ 以上になると光沢作用 が低下し，そのぶん，光沢剤の消耗が多くな る。つき⿱わり塩化亜鉛の濃度が $80 \mathrm{~g} / l$ 以上，塩化アンモニウムの濃度が $150 \mathrm{~g} / l$ 以 下の場合つき委わりが低下し，また光沢剂の 添加量が少ない場合る低下する。電流效率 は，塩化西鉛の濃度が $30 \mathrm{~g} / \mathrm{l}$ 以下，塩化アン モニウムが $250 \mathrm{~g} / \mathrm{l}$ 以上になると効率が 低下 する。

高電流部のコゲは, 光沢剤 ST-L の添加量 が影響大であり，添加量が少ないとコゲやす い。バレル班点は, 光沢剤 ST-L, 温度, $\mathrm{pH}$ の影響を多少受けるが，むしろ不純物の影響 のところで述べるが，めっき液中の鉄イオン の影響が大である。浴のにごりは，塩化亜鉛 の濃度が $80 \mathrm{~g} / \mathrm{l}$ 以上で温度が $37^{\circ} \mathrm{C}$ 以上の場 合，浴がにごりやすくなる。硬さは，2-4 項 の硬さのところでも述べたが， ST-L の添加 量が多い場合めっきが硬くなる傾向にある。

\section{3-2 不純物の影響}

表 3 は, 低濃度塩化亜鉛浴への不純物の影 響を示した。金属不純物で，6価クロム， 3 価クロム，ニッケル，銀などのイオンは，め っき後，クロメート後ともとれ汪ど大さな影 響は受けない。銅，鉛，鉄イオンは影響大で ある。特塩化浴の場合，鉄イオンが増えや
すいため注意しなければならない。

鉄イオンはバレルめっきの場合, 品物にバ レル目の斑点が出るので，定期的に過酸化水 素水処理により鉄を除去することが必要であ る。金属不純物が許容濃度以下であっても， 管理上，亜鉛未処理特よび活性炭处理を沪過 機に少量詰めて連続沪過を行ならことが必要 である。これにより, 光沢の均一化, 光沢剂 の消耗量を減少させることに好ましい結果を 与学る。

\section{4. 低濃度塩化浴の特異性}

表 4 （38ページ）は低濃度塩化浴, シアン 浴とジンケート浴を種々のことがらについて 比較したものである。まず生産性を比較した 場合，陰極電流効率が高いため，めっき速度 が大であり，生産性は他の浴に比べて大であ る。委た，ランニングコストも安価である。 光沢電流密度範囲も広く, 光沢レベリングは 他の浴汇比へて非常に優れている。均一電着 性，つきまわり，硬さに関してもシアン浴と 同等で非常に良い。さらに水素ぜい性が他の 浴に比べて，潘とんど起こらないことも重要 な特徴の一つである。

また，鋳物，高炭素鋼などシアン浴，ジン ケート浴では，直接めっきすることが困難な 品物に，程化浴では普通の軟鋼と同じような 工程でめっきができる。熱処理後の光沢, 有 色・黑色クロメートの色調がよい。ジンケー ト浴からのめっきではかなり悪くなる。浴は 安定であり，管理も非常に楽である。温度に

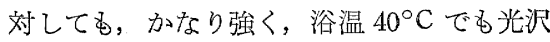
は維持できる。穼た浴電圧が, シアン浴, ジ

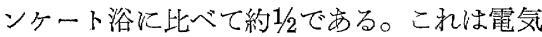
代が約 $1 / 2$ になることであり，コストダウンに なることになる。廃水処理も $\mathrm{pH}$ 調整のみで 非常に簡単である。以上のように, 種々の面で 低濃度塩化浴は優れた性質を持っている。 
表 3 低濃度塩化亜鉛めっき浴への不純物の影響

\begin{tabular}{|c|c|c|c|c|}
\hline 不純物と使用薬品 & 許容濃度 & $\begin{array}{l}\text { クロメート前 } \\
\text { の状態 }\end{array}$ & $\begin{array}{l}\text { クロメート後 } \\
\text { の状態 }\end{array}$ & 結果と処置方法 \\
\hline $\begin{array}{l}6 \text { 洒クロム } \\
10 \mathrm{~g} / l \mathrm{CrO} \\
\text { 溶液 }\end{array}$ & $3 \mathrm{mg} / \mathrm{l}$ & $\begin{array}{l}\text { 高電流密度部 } \\
\text { 分コゲを生ず } \\
\text { る。 }\end{array}$ & 異状なし & $\begin{array}{l}\text { 高電流部分にスターダスト状の } \\
\text { コゲを生ずる。極端には悪影響 } \\
\text { はない。還元する。 }\end{array}$ \\
\hline $\begin{array}{l}3 \text { 価クロム } \\
5 \mathrm{~g} / l \quad \mathrm{CrCl}_{3} \cdot 6 \mathrm{H}_{2} \mathrm{O} \\
\text { 溶液 }\end{array}$ & $9 \mathrm{mg} / \mathrm{l}$ & 異状なし & 異状なし & $\begin{array}{l}\text { めっき浴で黄緑色の沈殿を生じ } \\
\text { る。沪過により除去する。ステ } \\
\text { ンレスの溶解により混入する。 }\end{array}$ \\
\hline $\begin{array}{l}\text { ニッケル } \\
10 \mathrm{~g} / l \mathrm{NiCl}_{2} \cdot 7 \mathrm{H}_{2} \mathrm{O} \\
\text { 溶液 }\end{array}$ & $0.5 \mathrm{~g} / l$ & $\begin{array}{l}\text { 灰白色の縦縞 } \\
\text { を生ずる。 }\end{array}$ & 異状なし & $\begin{array}{l}\text { ニッケルに非常に強く少量では } \\
\text { やや光沢もよくなる。弱電解 } \\
\left(0.5 \sim 1 \mathrm{~A} / \mathrm{dm}^{2}\right) \text { か䓦鉛未処理 }\end{array}$ \\
\hline $\begin{array}{l}\text { 銅 } \\
10 \mathrm{~g} / l \quad \mathrm{CuCl}_{2} \cdot 2 \mathrm{H}_{2} \mathrm{O} \\
\text { 溶液 }\end{array}$ & $30 \mathrm{mg} / \mathrm{l}$ & 異状なし & $\begin{array}{l}\text { 硝酸 } \\
\text { クロメートに } \\
\text { より高電流お } \\
\text { よび低電流部 } \\
\text { が黒くなる。 }\end{array}$ & $\begin{array}{l}\text { かなり有害な不純物である。弱 } \\
\text { 電解、彗鉛米処理を行なう。 }\end{array}$ \\
\hline $\begin{array}{l}\text { 鉄 } \\
50 \mathrm{~g} / l \mathrm{FeCl}_{3}\end{array}$ & $0.5 \mathrm{~g} / l$ & $\begin{array}{l}\text { 疢白色の縦縞 } \\
\text { が生じ、高笔 } \\
\text { 流部がコゲや } \\
\text { すくなる。 }\end{array}$ & 異状なし & $\begin{array}{l}\text { めっき浴が赤褐色となり } 0.5 \mathrm{~g} / l \\
\text { 以上とけない。過酸化水素水処 } \\
\text { 理により沈殿除去。 }\end{array}$ \\
\hline $\begin{array}{l}\text { 鉛 } \\
5 \mathrm{~g} / l \mathrm{PbCl}_{2} \\
\text { 溶液 }\end{array}$ & $3.3 \mathrm{mg} / l$ & $\begin{array}{l}\text { 低電流部が若 } \\
\text { 干黒くなり、 } \\
\text { つまわりが } \\
\text { 低下する。 }\end{array}$ & 異状なし & $\begin{array}{l}\text { 最も有害な不純物であり } 0.5 \text { 1 } \\
\mathrm{A} / \mathrm{dm}^{2} て ゙ \text { 長期弱電解か事鉛未処 } \\
\text { 理を行なう。 }\end{array}$ \\
\hline $\begin{array}{l}\text { 銀 } \\
5 \mathrm{~g} / l \mathrm{AgNO}_{3} \\
\text { 溶液 }\end{array}$ & $10 \mathrm{mg} / \mathrm{l}$ & 異状なし & $\begin{array}{l}\text { 硝酸、クロメ } \\
\text { 一ト浸せきで } \\
\text { 低電流部分が } \\
\text { 黒くなる。 }\end{array}$ & $\begin{array}{l}0.5 \sim 1 \mathrm{~A} / \mathrm{dm}^{2} \text { で弱電解か亚鉛未 } \\
\text { 処理を行なう。 }\end{array}$ \\
\hline $\begin{array}{l}\text { 硝酸根 } \mathrm{NO}_{3}^{-} 10 \\
10 \mathrm{~g} / l \quad \mathrm{NaNO}_{3} \\
\text { 溶液 }\end{array}$ & $0.5 \mathrm{~g} / l$ & $\begin{array}{l}\text { 低電流部分の } \\
\text { 光沢がやや低 } \\
\text { 下寸る。 }\end{array}$ & 異状なし & 極端な悪影響はない \\
\hline $\begin{array}{l}\text { シアン } \mathrm{CN}^{-} \\
10 \mathrm{~g} / l \mathrm{NaCN} \\
\text { 溶液 }\end{array}$ & $1.5 \mathrm{mg} / l$ & $\begin{array}{l}\text { 陽極スライム } \\
\text { が発生する。 }\end{array}$ & 異状なし & $\begin{array}{l}\text { 陽極スライムが発生し、ザラッ } \\
\text { キの原因となる。 }\end{array}$ \\
\hline $\begin{array}{l}\text { 硫黄 } \mathrm{S}^{2-} \\
10 \mathrm{~g} / l \\
\mathrm{Na} 2 \mathrm{~S} \cdot 9 \mathrm{H}_{2} \mathrm{O} \\
\text { 溶液 }\end{array}$ & $40 \mathrm{mg} / l$ & $\begin{array}{l}\text { 光沢がややま } \\
\text { す。 }\end{array}$ & $\begin{array}{l}\text { クロメートに } \\
\text { より青色がや } \\
\text { やなくなる。 }\end{array}$ & 亚鉛未処理 \\
\hline $\begin{array}{l}\text { 硫酸根 } \mathrm{SO}_{4}{ }^{2-} \\
100 \mathrm{~g} / l \quad \mathrm{Na}_{2} \mathrm{SO}_{4} \\
\text { 溶液 }\end{array}$ & $20 \mathrm{~g} / l$ & $\begin{array}{l}\text { 高電流部にコ } \\
\text { ゲが生ずる。 }\end{array}$ & 異状なし & $\begin{array}{l}\text { 前処理に硫酸を使用した場合混 } \\
\text { 入され蓄積すると悪影響がある } \\
\text { ので前処理は塭酸を使用する。 }\end{array}$ \\
\hline
\end{tabular}

注）鉄が $0.2 \mathrm{~g} / \mathrm{l}$ 以上になると,パレルめっきの場合，品物にバレル目が出るのでバレル浴では注意が 必要である。 
表 4 各種浴の特徵の比較

\begin{tabular}{|c|c|c|c|}
\hline 比較項目 & 低濃度塩化浴 ST-L A-L & ジンケート浴 & シアン 浴 \\
\hline 生産性 & $\begin{array}{l}\text { めっき速度が大であるた } \\
\text { め生産性は大 }\end{array}$ & $\begin{array}{l}\text { 塩化浴に比べて生産性は } \\
\text { 悪い }\end{array}$ & $\begin{array}{l}\text { 塩化浴に比べて生産性は } \\
\text { 悪い }\end{array}$ \\
\hline $\begin{array}{l}\text { ランニング } \\
\text { コスト }\end{array}$ & 添加剂のコスト安価 & 添加剤のコスト高価 & $\begin{array}{l}\text { 添加剂のコストは安価で } \\
\text { あるが廃水処理を入れた } \\
\text { ら高価 }\end{array}$ \\
\hline $\begin{array}{l}\text { 光沢電流 } \\
\text { 密度範囲 }\end{array}$ & $\begin{array}{l}0.5 \sim 7\left(\mathrm{~A} / \mathrm{dm}^{2}\right) \\
1 \sim 5\left(\mathrm{~A} / \mathrm{dm}^{2}\right) \text { が最適 }\end{array}$ & $\begin{array}{l}0.5 \sim 5\left(\mathrm{~A} / \mathrm{dm}^{2}\right) \\
1 \sim 3\left(\mathrm{~A} / \mathrm{dm}^{2}\right) \text { が最適 }\end{array}$ & $\begin{array}{l}0.5 \sim 7\left(\mathrm{~A} / \mathrm{dm}^{2}\right) \\
1 \sim 5\left(\mathrm{~A} / \mathrm{dm}^{2}\right) \text { が最適 }\end{array}$ \\
\hline $\begin{array}{l}\text { 光 沢 } \\
\text { レベリング }\end{array}$ & $\begin{array}{l}\text { 光沢レベリングが非常に } \\
\text { よい }\end{array}$ & $\begin{array}{l}\mathrm{S} \mathrm{T}-\mathrm{L} \quad \mathrm{A}-\mathrm{L} \text { 浴に比 } \\
\text { ベレベリングが悪い }\end{array}$ & $\begin{array}{l}\mathrm{S} \mathrm{T}-\mathrm{L} \quad \mathrm{A}-\mathrm{L} \text { 浴に比 } \\
\text { べてレベリングが恵い }\end{array}$ \\
\hline 均一電着性 & $50 \sim 70 \%$ & $60 \sim 70 \%$ & $50 \sim 70 \%$ \\
\hline つきまうり & 非常によい & $\begin{array}{l}\text { 塩化浴およびシアン浴に } \\
\text { 比べ悪い }\end{array}$ & 非常によい \\
\hline 硬さ（Hv） & $50 \sim 70$ & $90 \sim 130$ & $30 \sim 70$ \\
\hline 水素ぜい性 & $\begin{array}{l}\text { めっき中には, ほとんど } \\
\text { 起こさない }\end{array}$ & $\begin{array}{l}\text { めっき中に水素ぜい性を } \\
\text { 起こす }\end{array}$ & $\begin{array}{l}\text { めっき中に水素ぜい性を } \\
\text { 起こす }\end{array}$ \\
\hline $\begin{array}{l}\text { 鋳物黑皮上の } \\
\text { めっき }\end{array}$ & $\begin{array}{l}\text { 直接めっきできる } \\
\text { 酸洗いでめっきできる }\end{array}$ & $\begin{array}{l}\text { 銅めっき後でないと不可 } \\
\text { 能、前操作してもつきに } \\
\text { くい }\end{array}$ & $\begin{array}{l}\text { 銅めっき後でないと不可 } \\
\text { 能、前操作してもつきに } \\
\text { くい }\end{array}$ \\
\hline $\begin{array}{l}\text { ベーキング後 } \\
\text { のクロメート }\end{array}$ & $\begin{array}{l}\text { クロメートの色調がほと } \\
\text { んど変わらない }\end{array}$ & $\begin{array}{l}\text { クロメートの色調が悪く } \\
\text { なる }\end{array}$ & $\begin{array}{l}\text { 塩化浴に比べると落ちる } \\
\text { が、ほとんど変わらない }\end{array}$ \\
\hline 浴の安定性 & 非常に安定 & $\begin{array}{l}\text { 安定性にかける } \\
\text { 薬品の補給に注意する }\end{array}$ & 非常に安定 \\
\hline 不純物の影響 & $\begin{array}{l}\text { 非常に敏感に影響をうけ } \\
\text { る }\end{array}$ & $\begin{array}{l}\text { 非常に敏感に影響をうけ } \\
\text { る }\end{array}$ & 影響を受けにくい \\
\hline 浴の管理 & 管理は非常に楽である & $\begin{array}{l}\text { 定期的な分析管理が必要 } \\
\mathrm{Zn} \mathrm{NaOH} \text { 添加剤の分析 }\end{array}$ & 管理は非常に楽である \\
\hline 浴 温 & $15 \sim 40^{\circ} \mathrm{C}$ & $15 \sim 35^{\circ} \mathrm{C}$ & $15 \sim 40^{\circ} \mathrm{C}$ \\
\hline 浴電圧 & $\begin{array}{l}\text { 静止 } 3 \sim 5 \mathrm{~V} \\
\text { バレル } 4 \text { (電気料か洝価) }\end{array}$ & $\begin{array}{ll}\text { 静止 } & 6 \sim 8 \mathrm{~V} \\
\text { バレル } & 7 \sim 12 \mathrm{~V} \\
\end{array}$ & $\begin{array}{ll}\text { 静止 } & 6 \sim 8 \mathrm{~V} \\
\text { バレル } & 7 \sim 12 \mathrm{~V} \\
\end{array}$ \\
\hline 廃水処理 & $\mathrm{pH}$ 調整のみ & $\mathrm{pH}$ 調整のみ & $\begin{array}{l}\text { シアン廃水処理設備が必 } \\
\text { 要、鉄シアン錯塩の処理 } \\
\text { が困難 }\end{array}$ \\
\hline
\end{tabular}




\section{5. おわり}

亜鉛めっき浴として, 低濃度塩化浴, ジン ケート浴和よびシアン浴があるが，招の拉の 長所もあれば短所もある。その浴の特徵を生 かすことが，最良の方法と言えよう。

低濃度填化浴の長所として，前章でも述べ たように，他の浴に比べてめっき速度が大で 生産性が向上する。水素ぜい性が他の浴に比 ベて起きにくいため, 自動車, 航空機部品の めっきなどに非常に適している。シアン浴や ジンケート浴では，直接めっきすることが困 難な鋳物，高炭素鋼などに直接めっきするこ
とができる。

あう一つの利点で，ジンケートでめっき後 ベーキング処理し，クロメート処理した場 合，変色するといら問題があるが，低濃度塩 化浴の場合そのような問題は起こらない。

しかし，短所としてめっき装置がアルカリ 浴に比べて腐食しやすいことがある。

以上のような点から，被めっき物の種類， 材質, 要求される性能によって低濃度塩化浴 の長所を生かしらる工場も多く，また，從来 の塩化浴に比べて均一電着性, 硬さが非常に 改良され，今後この低濃度塩化亚鉛浴が，公 害問題，省資源の面からも広く用いられると 考觉る。

\section{「アルミニウムのもうひとつの顔」}

一省資源省・エネルギー

\section{発行㪕金属協会}

軽金属協会では,「アルミニウムのあうひ そつの顔」といら小冊子を出している。アル ミニウムは，光や熱を反射する，加工しやす い，熱を层えやすい，電気をよく通す，さび にくい，軽い，美しい，強い，といった特性 があることは御承知の通り。
このアルミニウムが，私達の暮らしや社会 の中で省資源・省エネルギーの実現にも役立 っている「もらひとつ顔」を紹介している。

内容を紹介すると， メアルミサッシに替光

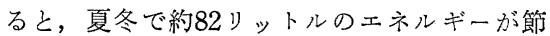
約 口自動車では， 1 年間で約 20 億りットル のガソリン節約 D地下鉄車両のアルミ化で 約 2,100 世帯の 1 力月分の電力を節約など。 [問合先]（社）軽金属協会 $\bar{T} 103$ 東京都中 央区日本橋 2-1-3 日本橋朝日生命館 శ్ర03 (273) 3041

な和申し込みは，軽金属協会へ，無料。

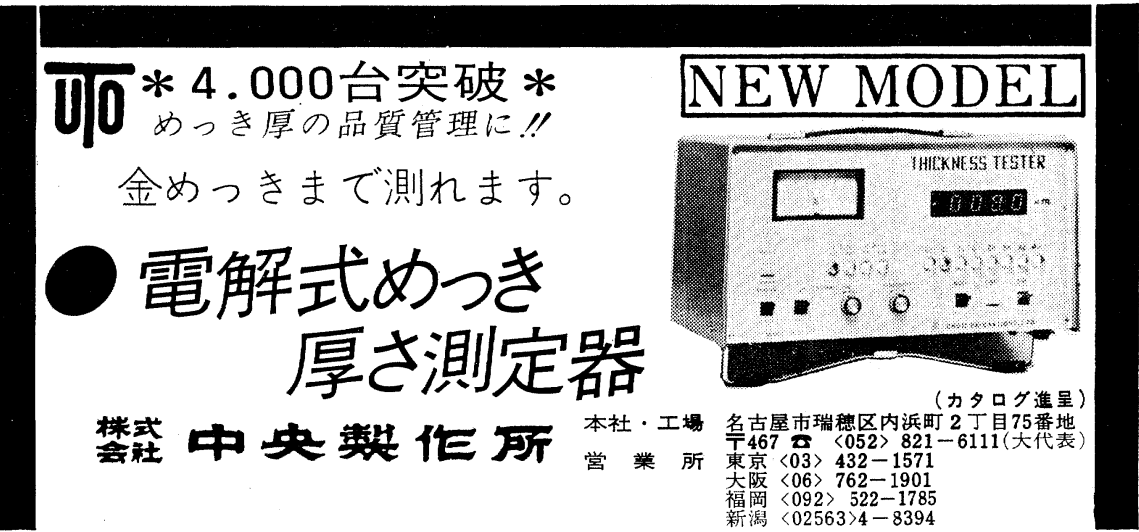

